\title{
ARE SUSTAINABLE INVESTMENTS CRISIS RESISTANT?
}

A study of the performance of ESG stock portfolios in crisis periods

Nóra Judit Szepesi ${ }^{1}$

An argument often voiced to support ESG investments is they are means to finance less risky industries and companies engaged in long-term sustainable operations. According to the author's research hypothesis, investors in crisis periods turn their attention to stocks rated high from an ESG aspect, and as a result of increased demand, portfolios set up from ESG stocks overperform the market to generate significant positive alpha. To test her hypothesis, the author analysed the alpha-generating performance of six different stock portfolios set up meeting different ESG screening criteria in crisis periods between January 2003 and December 2019 applying three asset pricing models. The findings unambiguously reject the research hypothesis. They are robust both for different crisis definitions and cut-offs for portfolio selection.

JEL codes: Go1, G11, G12, M14

Keywords: ESG, stock portfolios, performance assessment, crisis, Jensen alpha

\section{INTRODUCTION}

Sustainable development has been more and more in the foreground including the inclusion of sustainability aspects in financial decisions. As the lending policy of commercial banks is turning green (Pintér-Deutsch, 2012) investors are also striving to find sustainable investment opportunities, i.e. they consider the impact of companies on society and the environment when making investment decisions. (Gyura, 2019; MNB, 2019; Tapaszti, 2018). Finance studies forecast the popularity of sustainable investments to grow (Jónap, 2020), particularly as generation Y appear on the investment market (MSCI, 2020; Pereira, 2019) and the world emerges from the Corona virus (Jókuthy, 2020).

Aspects of sustainability may be considered in several ways, but in the end their goal is to provide sources for the so termed „triple-E” enterprises (Kuti, 2014:164) that exert less harmful external effects on their environment and on society.

1 Nóra Judit Szepesi is a graduate student in finance at Budapest Corvinus University. Email: nora. judit.szepesi@gmail.com. 
Investors, however, want to maximise the return of their investments eventually (Halbritter-Dorfleitner, 2015:25), thus, there are several studies analysing the connection between the financial performance of a company and its efforts made for sustainability. The latter is often measured using the so termed ESG rating. Depending on the company providing the figures, it condenses the impact the company in question exerts on the environment (E), society and employees (S), also considering corporate governance $(G)$ into a score or rating category.

The argument most often voiced for sustainable investment is that it allows you to invest into companies that are less risky, and their operation can be maintained long term. Linked to that idea, I assumed as my research hypothesis that in crisis periods investors turn their attention to the stocks of companies performing well ESG-wise and the increasing demand for such instruments results in their price declining less in a turbulent period as opposed to traditional stocks.

Provided investors' assumed behaviour holds, stock portfolios performing well from the aspect of ESG will overperform the market at times of market recession, i.e. they will be able to generate statistically significant positive alpha. To test my hypothesis, I set up 6 stock portfolios in total from Standard \& Poor's 500 index screened by different ESG criteria and analysed the performance of those actively managed portfolios in crisis periods between January 2003 and December 2019. To assess performance, I applied the alpha measured according to the CAPM, the Fama-French three-factor model (1993) and the Carhart four-factor model (1997).

\section{REVIEW OF THE MARKET OF SUSTAINABLE INVESTMENT}

I think it is important to define a few concepts connected to sustainable finance before embarking on a review of the studies on the performance of sustainable investments in crisis periods, which provide the theoretical framework of my study. You can come across several different concepts linked to sustainable finance, for instance, responsible investment, socially responsible investment, impact investment or green investment, which are often used as synonyms or inconsistently even in professional reports.

According to a 2012 report by GSIA (Global Sustainable Investment Alliance), "sustainable and responsible investment” $\left(\mathrm{SRI}^{2}\right)$ is an investment strategy that integrates financial analysis with environmental, social and governance (ESG) issues when making investment decisions (GSIA, 2012:36). According to the defi-

2 I use the acronym SRI for sustainable and responsible investment. In the literature it is also used for socially responsible investment. 
nition of the report, SRI investment is an umbrella concept covering responsible, socially responsible, impact and green investments.

Eurosif (European Social Investment Forum) also defines SRI as a long-term oriented investment approach which integrates ESG factors in the research, analysis and selection process of securities within an investment portfolio; it combines fundamental analysis and engagement with an evaluation of the ESG factors (Eurosif, 2018:12). US SIF (US Social Investment Forum) and Principles for Responsible Investment supported by the UN (UN PRI) also focus on ESG factors in their definition. Given that the definitions of different agencies are congruent regarding the concept of „sustainable and responsible investment”, I will use the terms 'SRI investment' and 'ESG investment' to refer to sustainable investment in this study. The above make it clear that nowadays sustainable investment represents the implementation of ESG factors (Alessandrini-Jondeau, 2019:2). In the EU application of the concept, sustainable finance means the integration of environmental, social and governance (ESG) factors into investment decisions to ensure financial stability (European Commission, 2018:1).

ESG factors can be implemented in investment decisions in several ways. The GSIA 2018 report differentiates 7 ESG strategies.

1) Applying negative screening, certain geographical sectors, companies or regions are excluded from investment funds or portfolios as ESG non-compatible (GSIA, 2018:7), i.e. companies that are active in „sinful” industries from an ethical or environmental perspective (e.g. tobacco industry, alcohol production, arms manufacturing, or gambling).

2) During best-in-class screening, investment is made in companies selected for positive ESG performance relative to industry peers (GSIA, 2018:7). The best-in-class approach is advantageous because it compensates for the effect that the ESG performance of industries may differ: some industries have higher environmental impact (e.g. oil industry), compared to commerce to be deemed more environmentally clean (Statman-Glushkov, 2009:38). The bestin-class approach can better reward company efforts made for sustainability.

3) A norms-based screening excludes companies from the investment universe if their business practices do not meet international norms (e.g. OECD, ILO, UN, UNICEF).

4) ESG integration means the systematic and explicit inclusion of environmental, social and governance factors into financial analysis (GSIA, 2018:7). It means the identification of ESG factors and their potential impact on company performance (UN PRI, 2018).

5) During themed investment, investment is made into assets specifically related to sustainability (e.g. green energy or sustainable agriculture). 
6) By impact investing, sources are provided for projects or companies aimed at solving social or environmental problems. So termed community investment is in the same category where capital is specifically directed to traditionally underserved individuals or communities (GSIA, 2018:7).

7) Shareholder action means the use of shareholder power to influence corporate behaviour (e.g. by communicating with senior management or filing shareholder proposals).

The 2018 GSIA report provides detailed description of the growth trends of SRI investment and the popularity of SRI strategies in 5 geographical regions (Australia and New-Zealand, Canada, Europe, Japan, the United States). At the beginning of 2018, the proportion of all SRI invested assets was $49 \%$ in Europe, $50 \%$ in Canada and $26 \%$ in the USA relative to total professionally managed assets (GSIA, 2018). As regards SRI strategies, negative screening seems to be the most popular approach (USD 19.8 billion out of the total of USD 30.7 billion at the start of 2018). It is followed by ESG integration (USD 17.5 billion) and shareholder action (USD 9.8 billion) (GSIA, 2018:3). There seems to be, however, a difference in the proportion of strategies between the regions; the leading SRI strategy was negative screening in Europe, shareholder action in Japan and ESG integration in the USA, Canada, and Australia.

Institutional investors (insurance companies and pension funds) are dominant on the demand side of the SRI investment market, but the proportion of retail investors has been growing for years: while institutional investors held $89 \%$ of SRI assets in 2012, the figure declined to $75 \%$ in 2018 in favour of retail investors (GSIA, 2018:12). The high proportion of institutional investors (e.g. pension funds, insurance companies) might be explained by their obligation to publish their investment principles and there is also social pressure preventing them from investing in companies that are active in „sin industries” (Hong-Kacperczyk, 2009:16).

\section{THE PERFORMANCE OF ESG INVESTMENT IN CRISIS PERIODS}

In line with the above definitions, investment is deemed sustainable if ESG factors are considered on setting up a portfolio. Both scholars and practitioners have been investigating for some decades the question of how the financial performance of sustainable investment compares to that of traditional investment neglecting social-environmental aspects.

The studies on the connection between sustainable performance and financial profitability can be divided into three main categories according to the methodology applied. 
1) The studies applying the method of event study (Capelle-Blancard-Petit, 2019; Krüger, 2015) analyse the impact of ESG relevant news items and events on equity returns.

2) The studies based on panel econometric modelling (Aouadi-Marsat, 2018; Ionescu et al., 2019; Yu et al., 2018) aim to reveal the connection between some financial indicators of companies (e.g. Tobin-Q, ROE, ROA), as a dependent variable and their ESG rating as an explanatory variable.

3) The third category of studies want to reveal the connection between ESG and financial performance by comparing the performance of traditional and ESG investment opportunities. The papers on the topic differ according to what they compare: the performance of an ESG index on the market to that of a traditional index (Tripathi-Bhandari, 2016), the performance of an ESG investment fund to that of a traditional investment fund (Becchetti et al., 2015; Matallín-Sáez et al., 2018; Nofsinger-Varma, 2014) or they set up ESG portfolios meeting different ESG screening criteria (Kempf-Osthoff, 2007; StatmanGlushkov, 2009), and evaluate their performance using risk adjusted performance indicators (e.g. Sharpe ratio, Treynor ratio, alpha parameters measured according to different asset pricing models).

Although several studies dealt with the connection between ESG and financial performance using different methodologies, they have failed to provide a clear picture on the direction of the relationship. While according to studies using the event study methodology, positive ESG-related news items have no impact on company value or the impact is not positive, in most econometric models the positive impact of the ESG score has been identified. The diverse findings could be influenced by most of the studies neglecting the impact of the stock market and/ or the macro-economic environment in their analysis. On the other hand, studies considering economic cycles in their analysis have found that ESG investments really performed better than the market in crisis periods (Becchetti et al., 2015; Nofsinger-Varma 2014; Tripathi-Bhandari, 2016).

The above papers dealing with ESG investment performance in crisis periods typically used the return figures of ESG investment funds and indices. As far as I know, the method of setting up ESG stock portfolios have not been used for crisis period analysis, so I hope to improve our knowledge of the performance of ESG investments during crises periods by offering a new aspect in this study.

Several arguments supported setting up my own stock portfolios. Some authors have pointed out it is unfortunate to work with the figures of investment funds, because their profit is not only influenced by ESG screening criteria but also by the performance of the fund manager (Derwall et al., 2005; Statman-Glushkov, 2009). Further, stock portfolios set up according to ESG scores are more reliable 
than a fund or index deemed sustainable, because the problem of "greenwashing" may arise in connection with ESG products, which means that a financial product may be deemed ESG but in fact it does not differ from a traditional investment opportunity (KPMG, 2020; Mihálovits-Tapaszti, 2018; Tapaszti, 2019)

\section{METHODOLOGY OF RESEARCH}

To examine my research hypothesis in line with the above considerations, I analysed the crisis-period performance of 6 stock portfolios set up according to different ESG strategies in the period from January 2003 to December 2019. I am going to describe the research hypothesis, the process of setting up the portfolios and the asset pricing models for measuring risk adjusted performance in this chapter. The findings are presented in chapter 5 and robustness tests are discussed in Chapter 6.

\subsection{Arguments to support the research hypothesis}

As mentioned above, the most frequently given argument for ESG investments is they are less risky and allow you to invest in companies that are long-term sustainable. Ionescu et al. (2019) emphasised investors focus their interest on companies displaying good ESG performance in crisis periods because of such characteristics (Ionescu et al., 2019, p. 830.). The phenomenon is also supported by the fact that investments made into SRI assets increased by $87.5 \%$ at the time of the global financial crisis between 2007 and 2009 compared to the $7 \%$ reduction of the total of professionally managed assets (Shkura, 2019:115). In addition, it was seen in the Corona virus crisis that ESG equity funds posted lower losses than their traditional counterparts (Czwick, 2020; Portfolio, 2020; Világgazdaság, 2020).

Accordingly, in line with my research hypothesis, sustainability is particularly highly valued by investors during crisis periods. Demand for shares performing well from an ESG aspect grows and as a result their price in turbulent periods declines less compared to traditional ones. If that assumed behaviour holds, stock portfolios set up according to ESG criteria can generate significant positive alpha in a market recession, i.e. they will overperform the market from the aspect of risk adjusted return.

A growing need for sustainability and stability will inevitably result in the general reduction of investments into stocks in a crisis period. Still, I believe investors in a crisis period will regroup their potentially shrinking investments with a preference for stocks deemed better for sustainability over traditional shares. According to my hypothesis, the restructuring of stock portfolios favouring instruments 
deemed better from the aspect of ESG and the accompanying increase in demand will provide support to the stock exchange price of ESG stocks at the time of a general recession of the stock market.

To test the hypothesis, I analysed the performance of 6 different portfolios set up according to ESG criteria, 3 of them with good and 3 with poor ESG performance in the period from January 2003 to December 2019. I used the S\&P 500 index for my investment universe and applied the alpha parameters calculated according to the CAPM, Fama-French (1993) and Carhart (1997) models.

\subsection{Portfolio setup}

The portfolios were set up based on a study by Kempf and Osthoff (2007) who had also designed their own portfolios. During the empirical study, I analysed the performance of 6 portfolios, 3 of which performed well, and 3 poorly from the aspect of ESG:

1) portfolio of „no sin” companies, active in „not sinful” industries (no_sin_eq)

2) $10 \%$ best-in-the-universe portfolio (BIU1o_eq)

3) $10 \%$ best-in-class portfolio (BIC1o_eq)

4) portfolio of companies active in „sin” industries (sin_eq)

5) $10 \%$ worst-in-the-universe portfolio (WIU1o_eq)

6) $10 \%$ worst-in-class portfolio (WIC1o_eq)

Portfolios 1)-3) meet ESG criteria but (4)-(6) portfolios performed quite poorly from an ESG aspect. The 'eq' in their names refers to their returns being equally weighted.

The investment universe of all the portfolios was the Standard \& Poor's 500 index, which means that a portfolio only included companies that were members of the S\&P 500 index and met the specific criteria related to the different portfolios.

I used equal weighting to calculate monthly portfolio return, where the portfolio return was the arithmetic average of the effective returns of shares constituting the portfolio as follows: $r_{\text {port } f, t}=\frac{\sum_{i=1}^{n} r_{i, t}}{n}, r_{i, t}=\frac{P_{i, t+1}}{P_{i, t}}-1$, where $r_{i, t}$ is the return of share $i$ in month $t$, and $P_{i, t}$ is the adjusted closing price of share $i$ on the first day of month $t$. So, the stock return in each month was calculated from the adjusted closing prices at the beginning of the next month and the beginning of the month in question using effective yield calculation.

All portfolios were adjusted annually, i.e. I did not monitor changes in the composition of S\&P 500 index during a year. If a share was excluded from the index during the year, I deemed it staying in the portfolio until the beginning of the 
next year when the portfolio was adjusted. This is conform with the methodology used by Kempf and Osthoff (2007), who set up their portfolio at the beginning of year $t$ and keep it unchanged until the end of year $t$ adjusting it during the year only if a company disappears from the database. Annual portfolio adjustment is often used in the literature (Derwall et al., 2005; Kempf-Osthoff, 2007; Statman-Glushkov, 2009), adjustment within a year is notused in practice due to the incurring transactional costs.

The composition of the portfolios only changed during a year if a share had been delisted or it had ceased to exist as an independent entity due to merger/acquisition or bankruptcy. In such cases I did not consider the return of the share in question to calculate portfolio return from the month of the event occurring and used the average of the returns of the remaining companies in the portfolio to calculate portfolio return. I could do so, as I assumed, following Kempf and Osthoff (2007), that I had sold the security at the last available price and had reinvested the amount from the sale into the remaining securities evenly distributed. Kempf and Osthoff (2007) analysed value-weighted portfolios, so they distributed the return from the sale in proportion to the value-weighting, but the logic is the same. I downloaded the figures needed for modelling, e.g. stock prices, data on the composition of the S\&P 500 index, ESG scores, industry and sector categories, closing prices of the S\&P 500 index using the Reuters Datastream Excel Add-in. I used the Thomson Reuters combined ESG scores, which measure the sustainability performance of companies on a scale $0-100 \%$. I downloaded the factor data and the 4-week US T-bill rate used as proxy to monthly risk-free return needed for the asset pricing models from the website of Kenneth R. French ${ }^{3}$.

\subsubsection{Portfolios of negative screening}

Applying the negative screening approach, I set up portfolio 'no_sin_eq' cleansed of companies active in „sinful" industries. For industry categories I used the Thomson Reuters Business Classification (TRBC) (Industry category) and excluded companies active in any of the following industries: Brewers, Distillers\&Wineries, Casinos\&Gaming, Tobacco, Uranium. A company had to meet two criteria to be in portfolio 'no_sin_eq': be a member of the S\&P 500 index at the beginning of the given year, and operate in an industry which had not been excluded.

As a counterpart to portfolio 'no_sin_eq', I set up portfolio 'sin_eq' covering companies that had been members of the S\&P 500 index at the beginning of the year and had operated in one of the industries listed above.

3 https://mba.tuck.dartmouth.edu/pages/faculty/ken.french/data_library.html (last downloaded: 05.04.2020) 


\subsubsection{Portfolios of positive screening}

The portfolio best-in-the-universe (BIU1o_eq) was set up as follows. A company could be included if it appeared in the S\&P 500 index at the beginning of the year in question and had to have a combined ESG score in the year preceding portfolio set up. I checked if both criteria (membership in the index and ESG score published in the previous year) were met using a VBA subroutine for each year analysed. The cut-off for portfolio selection was identified at 10\%, so I ranked the companies meeting both criteria by their ESG scores and the shares of the best performing $10 \%$ constituted the 'BIU10_eq' portfolio in the given year.

The same process was used for the portfolio worst-in-the-universe (WIU1o_eq), but the worst-performing $10 \%$ of the companies were selected. I used the Excel conditional format function to select the ESG-wise best and worst $10 \%$ of the companies. Since the portfolios were adjusted every year, the process was repeated for every year from January 2003 to December 2019.

\subsubsection{Portfolios 'best-in-class'}

Portfolio best-in-class (BIC1o_eq) was set up similarly to portfolio best-in-theuniverse albeit with a difference: here I also considered the sector a company was active in and the $10 \%$ best companies were selected by sectors.

Companies could be included if they were members of the S\&P500 index at the beginning of the year in question and had ESG scores in the previous year. They were categorised into 10 sectors using the TRBC Economic Sector classification, and I selected the best ESG-performing 10\% within them. Companies were not considered for the portfolio in a given year if there were no TRBC Economic Sector data available for them although they were members of the S\&P 500 index at the beginning of the year and also had ESG scores.

I calculated the monthly average of the effective returns of the best $10 \%$ of the companies in a sector and then the monthly average return for the whole best-inclass portfolio as the arithmetical average of the return of the 10 sub-portfolios assuming that the shares of different industries were distributed evenly in the portfolio. The same method was used for portfolio worst-in-class (WIU1o_eq) where the worst ESG-performing $10 \%$ of the companies were selected. 


\subsection{Identification of crisis periods}

To test my hypothesis, I had defined the basis upon which I deem a period (a month in my case) a crisis period. I regarded a month to be a crisis period if the return of the S\&P 500 index in the month fell below the monthly average return by a given standard deviation measured for the whole study period. Ishihara described such a definition of a crisis as valid (Ishihara, 2005:6). While authors analysing the performance of ESG investments in crisis periods typically identify a crisis according to macro-economic cycles (Becchetti et al., 2015; Matallín-Sáez et al., 2018; Tripathi-Bhandari, 2016), I differentiated between crisis and non-crisis periods on the basis of how the stock market evolved.

To check the robustness of the findings, I applied 5 different crisis definitions in total, which differed in the rate of standard deviation from the average (I analysed deviations of $1 ; 1.25 ; 1.5,2$ and 3 ).

\subsection{Asset pricing models to measure risk adjusted performance}

To measure the performance of the above 6 portfolios in a crisis period, I analysed the alpha parameters according to the 1) CAPM, the 2) Fama-French (1993) threefactor and the 3) Carhart (1997) four-factor models.

I estimated the following regression equations on OLS principle with the help of the gretl programme package:

$$
\begin{aligned}
& r_{i, t}-r_{f, t}=\alpha_{N C} D_{N C, t}+\alpha_{C} D_{C, t}+\beta\left(r_{m, t}-r_{f, t}\right)+\varepsilon_{i, t} \\
& r_{i, t}-r_{f, t}=\alpha_{N C} D_{N C, t}+\alpha_{C} D_{C, t}+\beta_{1}\left(r_{m, t}-r_{f, t}\right)+\beta_{2} S M B_{t}+\beta_{3} H M L_{t}+\varepsilon_{i, t} \\
& r_{i, t}-r_{f, t}=\alpha_{N C} D_{N C, t}+\alpha_{C} D_{C, t}+\beta_{1}\left(r_{m, t}-r_{f, t}\right)+\beta_{2} S M B_{t}+\beta_{3} H M L_{t}+\beta_{4} M O M_{t}+\varepsilon_{i, t}
\end{aligned}
$$

where:

$$
\begin{array}{ll}
\alpha_{N C}: & \text { alpha parameter in non-crisis period (indicator to measure risk ad- } \\
& \text { justed performance; regression intercept constant) } \\
\alpha_{C}: & \text { alpha parameter in crisis period } \\
D_{N C}: & \text { dummy variable indicating non-crisis months } \\
D_{C}: & \text { dummy variable indicating crisis months } \\
r_{i, t}: & \text { (equally weighted) return on portfolio } i \text { in month } t \\
r_{f, t}: & \text { 4-week US T-bill rate in month } t
\end{array}
$$


$r_{m, t}-r_{f, t}: \quad$ market factor (market risk premium in month $t$ )

$S M B_{t}: \quad$ "small minus big” factor in month $t$

$H M L_{t}: \quad$ "high minus low” factor in month $t$

$M O M_{t}: \quad$ momentum factor in month $t$

$\beta_{i, 1}, \beta_{i, 2}, \beta_{i, 3}$ : regression coefficients (estimated according to OLS principle) indicating the sensitivity of portfolio $i$ to given factors

$\varepsilon_{i, t}$ : difference of the risk premium of portfolio $i$ in month $t$ over the riskfree rate actually observed and the risk premium over the risk-free rate estimated by the model (deviation variable, residuum)

It is clear the dependent variable of asset pricing models was the premium of a given portfolio over the risk-free rate while the explanatory variables or control variables were factors typical of the given asset pricing model. I could analyse the crisis performance of the portfolios - following in the footsteps of Nofsinger and Varma (2004) - by breaking the alpha (intercept constant) of the asset pricing models using dummy variables $\left(\alpha_{N C} D_{N C, t}, \alpha_{C} D_{C, t}\right)$. In that way I had separate alpha parameters relating to a portfolio for crisis $\left(\alpha_{C}\right)$ and non-crisis $\left(\alpha_{N C}\right)$ periods.

Prior to interpreting the results, I checked if the criteria to apply the OLS estimation procedure had been met. The assumptions of the OLS method had been met except for the error members being uncorrelated. Autocorrelation of the residuum was treated - in a way accepted in the literature on the topic - by estimating all the models using Newey-West standard errors robust to heteroskedasticity and autocorrelation.

\section{RESEARCH FINDINGS}

According to my research hypothesis, portfolios displaying good ESG performance (no_sin_eq, BIU1o_eq, BIC10_eq) can, in crisis periods, overperform the market, i.e. they can generate significantly positive alpha $\left(\alpha_{C}\right)$ as opposed to portfolios questionable for ESG (sin_eq, WIU1o_eq, WIC1o_eq,).

Table 1 presents estimated alpha parameters (Alfa_C) of regressions in five crisis periods as defined by five different crisis definitions ${ }^{4}$, because if they are significantly positive, it proves a given portfolio was able to provide significantly better performance in crisis periods than market index investments.

4 Estimated non-crisis-period alpha parametres, the estimated coefficients of risk factors and the adjusted $\mathrm{R}^{2}$ indicators are also available on request. 
Table 1

Regression results for five different crisis definitions

\begin{tabular}{|c|c|c|c|c|c|}
\hline Alfa_C & Crisis (1) & Crisis (1.25) & $\begin{array}{c}\text { Crisis } \\
(1.5 \sigma)\end{array}$ & $\begin{array}{c}\text { Crisis } \\
(2 \sigma)\end{array}$ & $\begin{array}{c}\text { Crisis } \\
(3 \sigma)\end{array}$ \\
\hline \multicolumn{6}{|l|}{ no_sin_eq } \\
\hline CAPM & $-1.03 \%$ & $-1.11 \%$ & $-1.8 \% *$ & $-3.14 \% * * *$ & $-6.21 \% * * *$ \\
\hline Fama-French & $-0.9 \%$ & $-1.13 \%$ & $-1.68 \%$ & $-3.03 \% * * *$ & $-5.67 \% * * *$ \\
\hline Carhart & $-1.36 \% * *$ & $-1.51 \% * *$ & $-2.01 \% * *$ & $-3.69 \% * * *$ & $-5.79 \% * * *$ \\
\hline \multicolumn{6}{|l|}{ BIU10_eq } \\
\hline CAPM & $-1.64 \% * *$ & $-1.87 \% * *$ & $-2.69 \% * * *$ & $-3.97 \% * * *$ & $-6.85 \% * * *$ \\
\hline Fama-French & $-1.53 \% * *$ & $-1.86 \% * *$ & $-2.59 \% * * *$ & $-3.88 \% * * *$ & $-6.55 \% * * *$ \\
\hline Carhart & $-1.84 \% * * *$ & $-2.1 \% * *$ & $-2.8 \% * * *$ & $-4.32 \% * * *$ & $-6.62 \% * * *$ \\
\hline \multicolumn{6}{|l|}{ BIC10_eq } \\
\hline CAPM & $-1.55 \% * *$ & $-1.88 \% * *$ & $-2.79 \% * * *$ & $-4.43 \% * * *$ & $-6.7 \% * * *$ \\
\hline Fama-French & $-1.51 \% * *$ & $-1.89 \% * *$ & $-2.77 \% * * *$ & $-4.47 \% * * *$ & $-6.72 \% * * *$ \\
\hline Carhart & $-1.86 \% * *$ & $-2.16 \% * *$ & $-3.02 \% * * *$ & $-4.97 \% * * *$ & $-6.8 \% * * *$ \\
\hline \multicolumn{6}{|l|}{ sin_eq } \\
\hline CAPM & $-0.25 \%$ & $-0.82 \%$ & $-1.69 \%$ & $-2.71 \% *$ & $-3.09 \% * *$ \\
\hline Fama-French & $0 \%$ & $-0.61 \%$ & $-1.36 \%$ & $-2.26 \%$ & $-2.22 \%$ \\
\hline Carhart & $-0.4 \%$ & $-0.94 \%$ & $-1.66 \%$ & $-2.84 \% *$ & $-2.32 \%$ \\
\hline \multicolumn{6}{|l|}{ WIU10_eq } \\
\hline CAPM & $-0.99 \%$ & $-0.9 \%$ & $-2.09 \% *$ & $-3.07 \% * * *$ & $-4.86 \% * *$ \\
\hline Fama-French & $-0.89 \%$ & $-0.97 \%$ & $-2.03 \% *$ & $-3.05 \% * * *$ & $-4.34 \% * *$ \\
\hline Carhart & $-1.48 \% * *$ & $-1.45 \% *$ & $-2.46 \% * *$ & $-3.87 \% * * *$ & $-4.49 \% * * *$ \\
\hline \multicolumn{6}{|l|}{ WIC10_eq } \\
\hline CAPM & $-0.73 \%$ & $-0.97 \%$ & $-1.64 \% *$ & $-2.84 \% * * *$ & $-4.18 \% * * *$ \\
\hline Fama-French & $-0.71 \%$ & $-1.03 \%$ & $-1.66 \% *$ & $-2.91 \% * * *$ & $-4.13 \% * * *$ \\
\hline Carhart & $-1.14 \% * *$ & $-1.38 \% *$ & $-1.97 \% * *$ & $-3.52 \% * * *$ & $-4.24 \% * * *$ \\
\hline
\end{tabular}

Notes: Standard errors are robust for heteroskedasticity and autocorrelation (estimated using the Newey-West method).

The Table 1 includes monthly alphas.

***.**.* : indicate significance of variables at significance levels 1,5 and $10 \%$.

Source: own compilation (based on gretl outputs)

The portfolio of companies active in industries accepted from the ESG point of view (no_sin_eq) failed to generate positive significant alpha for any crisis definition or asset pricing model. On the contrary, you can find a significant negative alpha by the Carhart model for all crisis definitions with values varying between monthly $-1.36 \%$ and $-5.79 \%$, while for crisis definitions with standard deviation of 
2 and 3 , all three asset pricing models indicated significant negative alpha at the strictest $1 \%$ significance level.

As opposed to the hypothesis, portfolio 'BIU1o_eq' generated significant, negative abnormal return for all crisis definitions and asset pricing models. Monthly alpha values ranged from $-1.53 \%$ to $-6.85 \%$, and the alphas were significant at $1 \%$ significance level for crisis definitions with standard deviation of 1.5, 2 and 3 .

With respect to crisis period alpha, the results of portfolio 'BIC1o_eq', which includes the best $10 \%$ companies regarding their ESG scores that are active in 10 TRBC economic sectors, were quite similar to portfolio 'BIU1o_eq'. Crisis period alphas were negative and significant for all three asset pricing models and all five crisis definitions even at $1 \%$ significance level for crisis definitions with standard deviation of $1.5,2$ and 3 . Monthly alpha values ranged from $-1.51 \%$ to $-6.8 \%$.

Thus, it is clear the results received by modelling do not support the research hypothesis, since no positive significant alpha was found, on the contrary, significant negative alpha parameters were received for crisis periods in several cases.

\subsection{Crisis-period performance of portfolios 'sin' ESG}

Although the above results give an answer to the issues of the research hypothesis in its strict sense, it is also worth to analyse the crisis-period performance (Alfa_C) of portfolios with poor ESG scores (sin_eq, WIU1o_eq, WIC1o_eq), which is also included in Table 1.

The crisis-period alpha parameter of portfolio 'sin_eq' covering the shares of companies active in "sinful” industries is apparently not significant for 3 out of 5 crisis definitions, i.e. it is neither better nor worse than the market, but there is a significant negative alpha ranging from $-2.71 \%$ to $-3.09 \%$ for standard deviations 2 and 3.

Portfolio WIU1o_eq covering the worst 10\% companies regarding their ESG score in the previous year generated significant negative abnormal return in a crisis period with values ranging from $-1.48 \%$ to $-4.86 \%$ for several crisis definitions, particularly those with standard deviations of 2 and 3 .

Portfolio WIC1o_eq covering the worst 10\% companies regarding their ESG score and also considering sectoral categories also generated significant negative crisis-period alpha in the Carhart (1997) four-factor model $(-1.14 \%$ to $-1.38 \%)$ with standard deviations of 1 and 1.25. Significant negative alpha parameters were clear in all asset pricing models for all other crisis definitions.

Analysing the performance of the above three portfolios in crisis periods, you can state most portfolios set up from companies with poor ESG scores also generated negative significant alpha, i.e. they performed worse than the market. 


\subsection{Analysis of long-short portfolios}

Comparing the alpha parameters of counterpart portfolios (no_sin_eq - sin_eq, BIU1o_eq - WIU1o_eq, BIC1o_eq - WIC1o_eq) received in asset pricing models of the same type, it seems at first sight that ESG-good portfolios generated higher crisis-period negative alpha in absolute value, i.e. their performance related to the market was worse than that of ESG-poor portfolios.

To decide whether the alpha difference between good and bad portfolios was statistically significant, I ran regression models for the return series of long-short portfolios, which bought ESG-good portfolios (long position) and sold ESG-bad portfolios (short position). The three portfolios set up were termed 'nosin_sin_ls', 'BIU_ls' and 'BIC_ls'.

The regressions estimated for long-short portfolios were modified from the above inasmuch as the dependent variable of the models had become the difference of the return of the two portfolios measured in a given month rather than the premium exceeding the risk-free rate: (for portfolio 'nosin_sin_ls': $r_{\text {no_sin_eq,t }}-r_{\text {sin_eq,t }}$; for portfolio 'BIU10_ls': $r_{\text {BIU10_eq,t }}-r_{\text {WIU10_eq,t }}$ and for portfolio 'BIC10_ls': $\left.r_{\text {BIC10_eq,t }}-r_{\text {WIC10_eq, }}\right)$.

Provided the alpha parameter estimated for the long-short portfolio is significant, the difference between the performance of the two portfolios must be deemed statistically significant. The sign of the parameter indicates if the alpha parameter of the "good-ESG" portfolio is lower or higher than the alpha of the portfolio of the relevant „bad-ESG” portfolio. Table 2 includes the results for different crisis definitions.

In the case of portfolio nosin_sin_ls', crisis-period alphas $(-3.45 \%$ and $-3.46 \%)$ were only significant by the Fama-French (1993) and the Carhart (1997) models for crisis definition with standard deviation of 3 . This means that at the time of major recessions on the stock market, indicated by crisis definition with standard deviation of 3 , the ESG-good portfolio 'nosin_eq' provided significantly worse risk adjusted performance based on its alpha than portfolio 'sin_eq' covering companies active in sin industries.

Portfolio 'BIU1o_ls' did not generate significant crisis-period alpha by any of the crisis definitions, which indicates the difference in the alphas of portfolios 'BIU10_eq' and 'WIU10_eq' was not significant statistically; you cannot say one or the other portfolio strategy would perform better in a crisis period.

In the case of portfolio 'BIC1o_ls', all alphas were significant and negative for all crisis definitions and in all asset pricing models; the figures ranged from $-0.71 \%$ to $-2.59 \%$. This means portfolio 'BIC10_eq' did not only perform significantly worse than the market in crisis periods, but its performance was significantly worse than that of portfolio'WIC10_eq' covering the 10\% companies with the worst ESG scores. 
Thus, long-short portfolio strategies revealed that in a crisis period two out of three ESG-positive portfolios did not only perform worse than the market but also worse than their ESG-bad counterpart.

Table 2

Regression models for long-short portfolios for different crisis definitions

\begin{tabular}{cccccc}
\hline Alfa_C & Crisis (1) & Crisis (1.25) & $\begin{array}{c}\text { Crisis } \\
(1.5 \sigma)\end{array}$ & $\begin{array}{c}\text { Crisis } \\
(2 \sigma)\end{array}$ & $\begin{array}{c}\text { Crisis } \\
(3 \sigma)\end{array}$ \\
\hline nosin_sin_ls & & & & & \\
CAPM & $-0.78 \%$ & $-0.29 \%$ & $-0.1 \%$ & $-0.43 \%$ & $-3.12 \%$ \\
Fama-French & $-0.9 \%$ & $-0.52 \%$ & $-0.32 \%$ & $-0.78 \%$ & $-3.45 \% *$ \\
Carhart & $-0.97 \%$ & $-0.56 \%$ & $-0.36 \%$ & $-0.85 \%$ & $-3.46 \% *$ \\
\hline BIU_ls & & & & & $-0.9 \%$ \\
CAPM & $-0.64 \%$ & $-0.97 \%$ & $-0.6 \%$ & $-1.99 \%$ \\
Fama-French & $-0.64 \%$ & $-0.88 \%$ & $-0.56 \%$ & $-0.83 \%$ & $-2.2 \%$ \\
Carhart & $-0.36 \%$ & $-0.66 \%$ & $-0.35 \%$ & $-0.46 \%$ & $-2.13 \%$ \\
\hline BIC_ls & & & & & \\
CAPM & $-0.82 \% * *$ & $-0.9 \% * *$ & $-1.14 \% * *$ & $-1.59 \% * *$ & $-2.52 \% * * *$ \\
Fama-French & $-0.8 \% *$ & $-0.86 \% *$ & $-1.11 \% * *$ & $-1.55 \% * *$ & $-2.59 \% * * *$ \\
Carhart & $-0.71 \% *$ & $-0.78 \% *$ & $-1.04 \% *$ & $-1.45 \% *$ & $-2.56 \% * * *$ \\
\hline
\end{tabular}

Notes: Standard errors are robust for heteroskedasticity and autocorrelation (estimated using the Newey-West method).

The Table 2 includes monthly alphas.

${ }^{* * *} .{ }^{* *} .{ }^{*}$ : indicate significance of variables at significance levels 1.5 and $10 \%$.

Source: own compilation (based on Gretl outputs)

\section{ROBUSTNESS TEST AND FURTHER RESEARCH OPTIONS}

To test the robustness of my research findings, I checked the performance of the best-in-the-universe and best-in-class portfolios applying two different cut-offs for portfolio selection for all five crisis definitions.

In addition to the initially applied 10\% cut-off, I also used cut-off at 5\% and $25 \%$ to set up portfolios; i.e. in the case of the best-in-the-universe approach, portfolio BIU5_eq, BIU25_eq includes the globally best performing 5\% and $25 \%$ companies regarding their ESG scores, while in the case of best-in-class, I selected the best $5 \%$ and $25 \%$ considering sectoral categorisation (BIC5_eq, BIC25_eq). Table 3 includes the regression results. 
Table 3

Robustness test for different crisis definitions

\begin{tabular}{|c|c|c|c|c|c|}
\hline Alfa_C & $\begin{array}{l}\text { Crisis } \\
(1 \sigma)\end{array}$ & $\begin{array}{c}\text { Crisis }(1.25 \\
\sigma)\end{array}$ & $\begin{array}{c}\text { Crisis } \\
(1.5 \sigma)\end{array}$ & $\begin{array}{l}\text { Crisis } \\
(2 \sigma)\end{array}$ & $\begin{array}{l}\text { Crisis } \\
(3 \sigma)\end{array}$ \\
\hline \multicolumn{6}{|l|}{ BIU5_eq } \\
\hline CAPM & $-1.61 \% * *$ & $-2.03 \% * *$ & $-3.25 \% * * *$ & $-4.49 \% * * *$ & $-6.45 \% * * *$ \\
\hline Fama-French & $-1.6 \% *$ & $-2.04 \% * *$ & $-3.27 \% * * *$ & $-4.56 \% * * *$ & $-6.58 \% * * *$ \\
\hline Carhart & $-1.9 \% * *$ & $-2.28 \% * *$ & $-3.49 \% * * *$ & $-5 \% * * *$ & $-6.65 \% * * *$ \\
\hline \multicolumn{6}{|l|}{ BIU25_eq } \\
\hline CAPM & $-1.3 \% *$ & $-1.4 \%$ & $-2.07 \% * *$ & $-3.43 \% * * *$ & $-5.77 \% * * *$ \\
\hline Fama-French & $-1.18 \%$ & $-1.41 \% *$ & $-1.96 \% * *$ & $-3.33 \% * * *$ & $-5.28 \% * * *$ \\
\hline Carhart & $-1.64 \% * * *$ & $-1.78 \% * *$ & $-2.29 \% * * *$ & $-3.97 \% * * *$ & $-5.39 \% * * *$ \\
\hline \multicolumn{6}{|l|}{ BIC5_eq } \\
\hline CAPM & $-1.77 \% * *$ & $-2.11 \% * *$ & $-2.7 \% * *$ & $-3.89 \% * * *$ & $-6.69 \% * * *$ \\
\hline Fama-French & $-1.76 \% * *$ & $-2.1 \% * *$ & $-2.69 \% * *$ & $-3.93 \% * * *$ & $-6.85 \% * * *$ \\
\hline Carhart & $-2.18 \% * * *$ & $-2.44 \% * *$ & $-2.99 \% * *$ & $-4.51 \% * * *$ & $-6.95 \% * * *$ \\
\hline \multicolumn{6}{|l|}{ BIC25_eq } \\
\hline CAPM & $-1.23 \% *$ & $-1.28 \% *$ & $-1.72 \% * *$ & $-3.13 \% * * *$ & $-5.74 \% * * *$ \\
\hline Fama-French & $-1.15 \%$ & $-1.29 \% *$ & $-1.65 \% *$ & $-3.08 \% * * *$ & $-5.48 \% * * *$ \\
\hline Carhart & $-1.54 \% * *$ & $-1.6 \% * *$ & $-1.92 \% * *$ & $-3.62 \% * * *$ & $-5.58 \% * * *$ \\
\hline
\end{tabular}

Comments: Standard errors are robust for heteroskedasticity and autocorrelation (estimated using the Newey-West method).

The Table 3 includes monthly alphas.

${ }^{* * *}$. ${ }^{* *} .{ }^{*}$ : indicate significance of variables at significance levels 1,5 and $10 \%$.

Source: own compilation (based on Gretl outputs)

As for strategy best-in-the-universe, neither portfolio could generate significant positive alpha in crisis periods in any asset pricing model or for any crisis definition, which confirms the rejection of the research hypothesis. Portfolio 'BIU5_eq' generated significant negative alpha for all crisis definitions and asset pricing models. Portfolio 'BIU25_eq' generated significant negative alpha in all asset pricing models with standard deviations of 1.5, 2 and 3, and no positive alpha was generated for crisis definitions with standard deviations of 1 and 1.25.

Linked to the best-in-class strategy, portfolio 'BIC5_eq' - just as portfolio 'BIU 5 eq' - generated significant, negative abnormal return with figures ranging from monthly $-1.76 \%$ to $-6.95 \%$ for all crisis definitions and asset pricing models. Portfolio 'BIC25_eq' generated significant negative alpha for 4 crisis definitions and for all asset pricing models, and no significant positive alpha could be found for crisis definition with standard deviation of 1. 
Applying several components to check robustness, the findings of my research indicate the same direction, i.e. the rejection of the research hypothesis, despite several studies in the literature having proved the opposite. I suggest the research should be repeated applying a crisis definition that uses macroeconomic cycles rather than the evolution of the stock market for crisis definition. The two approaches identify different periods of time as crisis periods, which could explain the difference between my findings and those presented in the literature.

Comparing, for instance, the crisis periods I defined with the expansive and contracting sections on the USA market published by the National Bureau of Economic Research (NBER) ${ }^{5}$, the difference is obvious. Taking the 2008 global financial crisis for an example, the NBER defined the whole period from January 2008 to June 2019 (18 months) as one uninterrupted crisis period, while the approach of stock market trends for crisis definition I applied resulted in 8 out of 18 months to be deemed crisis periods (crisis months) for a crisis definition with standard deviation of 1. Furthermore, the crisis months were not consecutive within the period, but they were scattered in time.

\section{SUMMARY}

This is a study in the field of research on sustainable investment, which analyses the connection between company efforts made for sustainability and financial performance.

According to my research hypothesis, sustainability and long-term value creation gain added value in crisis periods, and as a result, investors' stock portfolios are restructured in the direction of shares performing well from an ESG aspect. Provided my assumptions are correct, stock portfolios deemed good from the aspect of ESG should generate significant positive alpha in crisis periods, i.e. they should overperform the market.

To test the hypothesis, using the S\&P 500 index, I set up 6 portfolios applying different ESG-screening criteria (negative, positive and best-in-class) and analysed their performance in crisis periods from January 2003 to December 2019. To measure risk adjusted performance, I used regression alpha parameters calculated by means of the CAPM, Fama-French (1993) and Carhart (1997) models. The regression results clearly suggest the research hypothesis should be rejected. None of the three portfolios performing well from an ESG aspect generated significant positive alpha for any asset pricing model, on the contrary, they per-

5 https://www.nber.org/ (last downloaded on: 29.05.2020) 
formed significantly worse than the market in several cases. The results are robust both for different crisis definitions and for the cut-off of portfolio composition. The analysis of long-short portfolios also revealed that, in the case of negative and best-in-class screening, ESG-positive portfolios did not only significantly underperform the market but also the counterpart ESG-negative portfolios.

To sum up, my findings failed to prove the research hypothesis. Considering, however, that I linked the definition of crisis to the evolution of the stock market, it would be worth to repeat the analysis in future applying a crisis definition based on macroeconomic considerations, as the crisis definition applied may have a significant impact on the results.

\section{REFERENCES}

Alessandrini, F. - Jondeau, E. (2020): ESG Investing: From Sin Stocks to Smart Beta. The Journal of Portfolio Management Ethical Investing 46(3), 75-94, https://doi.org/10.3905/jpm.2020.46.3.075.

Aouadi, A. - Marsat, S. (2018): Do ESG Controversies Matter for Firm Value? Evidence from International Data. Journal of Business Ethics 151, 1027-1047, https://doi.org/10.1007/s10551-016-3213-8.

Becchetti, L. - Ciciretti, R. - DAlò, A. - Herzel, S. (2015): Socially responsible and conventional investment funds: performance comparison and the global financial crisis. Applied Economics 47(25), 2541-2562, https://doi.org/10.1080/00036846.2014.1000517.

Capelle-Blancard, G. - Petit, A. (2019): Every Little Helps? ESG News and Stock Market Reaction. Journal of Business Ethics 157, 543-565, https://doi.org/10.1007/s10551-017-3667-3.

Carhart, M. M. (1997): On Persistence in Mutual Fund Performance. The Journal of Finance 7(1), $57-82$.

Derwall, J. - Guenster, N. - Bauer, R. - Koedijk, K. (2005): The Eco-Efficiency Premium Puzzle. Financial Analysts Journal 61(2), 51-63, https://doi.org/10.2469/faj.v61.n2.2716.

Fama, E. F. - French, K. R. (1993): Common Risk Factors in the Returns on Stocks and Bonds. Journal of Financial Economics 33, 3-56, https://doi.org/10.1016/0304-405x(93)90023-5.

Halbritter, G. - Dorfleitner, G. (2015): The Wages of Social Responsibility - Where Are They? A Critical Review of ESG Investing. Review of Financial Economics 26, 25-35, https://doi. org/10.1016/j.rfe.2015.03.004.

Hong, H. - KaCPERCZy K, M. (2009): The price of sin: The effects of social norms on markets. Journal of Financial Economics 93, 15-36, https://doi.org/10.1016/j.jfineco.2008.09.001.

Ionescu, G. H. - Firoiu, D. - Pirvu, R. - Vilag, R. D. (2019): The Impact of ESG Factors on Market Value of Companies From Travel and Tourism Industry. Technological and Economic Development of Economy 25(5), 820-849, https://doi.org/10.3846/tede.2019.10294.

Kempf, A. - Osthoff, P. (2007): The Effect of Socially Responsible Investing on Portfolio Performance. European Financial Management 13(5), 908-922, https://doi.org/10.1111/j.1468036x.2007.00402.x.

KRÜGER, P. (2015): Corporate goodness and shareholder wealth. Journal of Financial Economics 115(2), 304-329, https://doi.org/10.1016/j.jfineco.2014.09.008.

Kuti, Mónika (2014): A fenntarthatóság és a pénzügyek integrálhatóságának kihívásai [Challenges of sustainability and financial integration]. Hitelintézeti Szemle, 13(2), 164-173. 
Matallín-Sáez, J. C. - Soler-Domínguez, A. - De Mingo-López, D. V. - Tortosa-Ausina, E. (2018): Does socially responsible mutual fund performance vary over the business cycle? New insights on the effect of idiosyncratic SR features. Business Ethics: A European Review 28(1), 71-98, https://doi.org/10.1111/beer.12196.

Nofsinger, J. R. - Varma, A. (2014): Socially Responsible Funds and Market Crises. Journal of Banking \& Finance 48, 180-193, https://doi.org/10.1016/j.jbankfin.2013.12.016.

Pintér, Éva - Deutsch, Nikolett (2012): Fenntartható fejlődés elvei és azok érvényre jutása a banki gyakorolatban II. [Principles of sustainable development and their implementation in banking practice II.] Vezetéstudomány 43(1), 57-63.

SHKURA, I. (2019): The regional peculiarities of SRI development. Journal of Economics and Management 37(3),107-138, http://doi.org/10.22367/jem.2019.37.06.

Statman, M. - Glushkov, D. (2009): The Wages of Social Responsibility. Financial Analysts Journal 65(4), 33-46, https://doi.org/10.2469/faj.v65.n4.5.

Tripathi, V. - Bhandari, V. (2016): Performance Evaluation of Socially Responsible Stocks Portfolios across Sectors during Different Economic Conditions. Journal of Management Research 16(2), 87-105.

Yu, E. P. - GUO, C. Q. - VAN LuU, B. (2018): Environmental, social and governance transparency and firm value. Business Strategy and the Environment 27(7), 987-1004, https://doi.org/10.1002/ bse.2047.

\section{Internet sources:}

CzwICK, DÁvid (2020): Válság idején felülteljesítik a piacokat az ESG-termékek [ESG products overperform the market in crisis periods]. (Világgazdaság online, 25.05.2020), https://www.vg.hu/ penzugy/penzugyi-hirek/valsag-idejen-felulteljesitik-a-piacokat-az-esg-termekek-2-2278341/ (last downloaded at 02.06.2020).

EC (2018): European Commission's definition of sustainable finance (https://eur-lex.europa.eu/legalcontent/EN/TXT/PDF/?uri=CELEX:52018DCoo97\&from=EN, last downloaded at 09.04.2020).

Eurosif (2018): European SRI Study 2018 (Report 2018), http://www.eurosif.org/wp-content/uploads/2018/11/European-SRI-2018-Study.pdf (last downloaded at 18.04.2020).

GSIA (2012): Global Sustainable Investment Review, 2012 (GSIA Report 2012), http://gsiareview2012. gsi-alliance.org/pubData/source/Global\%2oSustainable\%2oInvestement\%2oAlliance.pdf (last downloaded at 03.06.2020).

GSIA (2018): Global Sustainable Investment Review, 2018 (GSIA Report 2018), http://www.gsialliance.org/wp-content/uploads/2019/03/GSIR_Review2018.3.28.pdf (last downloaded at 18.04.2020).

Gyura, GÁbor (2019): Zöld pénzügyek Magyarországon: mi kell az áttöréshez? [Green finance in Hungary: what do you need for a breakthrough] (https://www.mnb.hu/letoltes/19-08-15-gyuragabor-zold-penzugyek.pdf, last downloaded at 03.06.2020).

Ishihara, Y. (2005): Quantitative Analysis of Crisis: Crisis Identification and Causality [online], World Bank Policy Research Working Paper 3598, https://doi.org/10.1596/1813-9450-3598, http:// documents.worldbank.org/curated/en/754211468268180233/pdf/wps3598.pdf (last downloaded at 19.04.2020).

JóKUTHY, LAURA (2020): Lehet zöld a gazdasági újrakezdés? [Can economic restart green?] (https:// www.mnb.hu/letoltes/jokuthy-laura-zold-taxonomomia.pdf, last downloaded at 03.06.2020).

JóNAP, RicháRD (2020): Hat jóslat a 2020-as évekre - a világ nagyot változhat [Six forecasts for the 2020 s - the world can change much] (Concorde blog, 07.01.2020, http://concordeblog. hu/2020/01/o7/hat-joslat-a-2020-as-evekre/ (last downloaded at 02.06. 2020). 
Mihálovits, Zsolt - TAPAszti, Attila (2018): Zöldkötvények, avagy a zöld számtalan árnyalata [Green stocks, or the innumerable shades of green] (https://www.mnb.hu/letoltes/mihalovitstapaszti-zoldkotvenyek-avagy-a-zold-szamtalan-arnyalata.pdf, last downloaded at 03.06.2020).

KPMG (2020): Sustainable Investing: fast-forwarding its evolution - KPMG Report (2020. február), https://assets.kpmg/content/dam/kpmg/xx/pdf/2020/o2/sustainable-investing.pdf (last downloaded at 2020.02.12.).

MNB (2019): Zöld pénzügyek Magyarországon - Konzultációs dokumentum [Green finances in Hungary - Consultation document] (https://www.mnb.hu/letoltes/zold-penzugyek-konzultacios-dokumentum-2.pdf (last downloaded: 21.04.2020).

MSCI (2020): Swipe to invest: the story behind millennials and ESG investing - MSCI ESG Research LLC (2020. március), https://www.msci.com/documents/10199/o7e7a7d3-59c3-4dob-bob5o29e8fd3974b (last downloaded at 12.02.2020).

Pereira, E. (2019): Millennials champion the ESG revolution [online]. Investment Europe.net, https://www.investmenteurope.net/opinion/4001947/millennials-champion-esg-revolution (last downloaded at 13.02.2020).

TAPAszTi, ATtila (2018): Társadalmi és környezeti hatású befektetések, ESG: üres hívószavak vagy szükségszerű változások? [Social and environmental-impact investment, ESG: empty slogans or necessary changes?] (https://mnbtanszekblog.hu/2018/11/23/tarsadalmi-es-kornyezetihatasu-befektetesek-esg-ures-hivoszavak-vagy-szuksegszeru-valtozasok/, last downloaded at 01.06.2020).

TAPASZTi ATtila (2019): Érkeznek a karboncsökkentett indexek? Válaszcikk egyvideóra [Are carbonreduced indexes coming? Reply to a video] (https://mnbtanszekblog.hu/2019/10/24/erkeznek-akarboncsokkentett-indexek-valaszcikk-egy-videora/, last downloaded at 02.06.2020).

US SIF (2020): Sustainable Investing Basics (US SIF definition for sustainable investment), https:// www.ussif.org/sribasics (last downloaded at 07.03.2020).

Portfolio (2020): Válságálló befektetésnek bizonyultak az ESG-alapok [Have ESG funds proved crisis resistant?] (04.05.2020), https://www.portfolio.hu/befektetes/20200504/valsagallo-befektetesnek-bizonyultak-az-esg-alapok-429732 (last downloaded at 01.06.2020)

Világgazdaság (2020): Válságállónak bizonyultak az ESG befektetések [Have ESG investments proved crisis resistant?] (26.05.2020), https://www.vg.hu/penzugy/penzugyi-hirek/valsagallonak-bizonyultak-az-esg-befektetesek-2281932/ (last downloaded at 03.06.2020).

UN PRI (2018): What is ESG integration? (https://www.unpri.org/investor-tools/what-is-esg-integration/3052.article, last downloaded at 07.03.2020).

UN PRI (n. d.) What is responsible investment? (https:/www.unpri.org/pri/an-introduction-toresponsible-investment/what-is-responsible-investment, last downloaded at 07.03.2020). 